\title{
Precarious Sovereignty in a Post-liberal Europe: The COVID-19 Emergency in Estonia and Finland
}

\author{
Andrey Makarychev ${ }^{1} \cdot$ Tatiana Romashko $^{2}$
}

Received: 20 June 2020 / Accepted: 29 September 2020 / Published online: 23 October 2020

(c) Fudan University 2020

\begin{abstract}
The paper addresses a puzzle resulting from the current global state of alert: the coronavirus pandemic brought us back to the world of the allegedly sovereign nation states with borders and national governments in charge, yet in fact, this retrieved sovereignty looks very vulnerable and precarious. We explain this controversy through a triad of concepts - sovereignty, governmentality, and post-liberalismthat we apply to an analysis of a corona-imposed state of emergency in Estonia and Finland. Based on comparative case study research, we posit that sovereignty is precarious in post-liberalism due to its large dependence on the technologies of responsibilization and agency. From a biopolitical perspective, a major point in the anticrisis management is to convince people to sacrifice personal liberties for the sake of public safety. These issues of governmentality will be dealt with based on critical discourse analysis and media analysis in Estonia and Finland.
\end{abstract}

Keywords Coronavirus $\cdot$ Estonia $\cdot$ Finland $\cdot$ Precarious sovereignty $\cdot$ Smooth governance $\cdot$ Governmentality $\cdot$ Responsibilization $\cdot$ Agamben $\cdot$ Foucault

\section{Introduction}

This article stems from the general presumption that the COVID-19 crisis in 2020 is a major shaper of the ongoing transformation of the liberal international order. On the surface, it seems that traditional nation-state-based territoriality is re-emerging as there are growing demands for key elements of national sovereignty-borders, checkpoints, and other elements of a security infrastructure. Yet, the global state of

Andrey Makarychev

andrey.makarychev@ut.ee

Tatiana Romashko

tatiana.t.romashko@jyu.fi

1 University of Tartu, Johan Skytte Institute of Political Studies, Tartu, Estonia

2 Department of Social Sciences and Philosophy, University of Jyväskylä, Jyvaskyla, Finland 
alert, which is being largely administered by sovereign governments, has unveiled the vulnerability of sovereignty under exceptional circumstances. Discussions on this paradox are not new, and there have been plenty of voices in academia who, for decades, have been sceptical about the ability of national governments to protect their citizens from terrorism or properly take care of millions of refugees and internally displaced persons.

The recovered sovereignty, indeed, looks vulnerable and precarious, which is particularly visible in Europe as a hotbed of post-liberal transformations, which test the ability of the EU and its member states to mitigate the implications of the restrictions imposed upon the population. We use the concept of precarious sovereignty as an inverted replica of Judith Butler's idea of 'precarious life', thus pointing to the fragility of sovereign power in times of emergency. The conceptualisation of sovereignty as precarious implies its dependence on what the French political philosopher Michel Foucault dubbed governmentality and its actors-medical professionals, hospital personnel, municipal authorities, and volunteer organisations-all those working on the frontline of crisis management. We argue that the COVID-19 emergency has exposed the mutual correlation and interdependence between the state of exception - as a prerogative of the sovereign power-and the routine techniques of governance grounded in a balance of responsibilities between the rulers and the governed. This nexus of sovereignty and governance is inherently controversial: on one hand, to fulfil its responsibilities to the people, the state concentrates more power in its hands, yet, on the other hand, the state acts along the lines of Foucault's concept of 'responsibilization'-individual practices of taking care of ourselves and managing our corporeal lives to minimise or avoid possible risks.

This article addresses this controversy in two states of the Baltic Sea Region, Finland and Estonia. Three interrelated concepts-sovereignty, governmentality, and post-liberalism-form the conceptual triad for our analysis. Applying these notions, we examine the way in which the governments of Estonia and Finland tackled the spread of the virus within the national borders and adjusted governmental mechanisms to fight the pandemic. The article pursues three research questions. First, how were the crisis and the 'state of exception' articulated by the respective governments and other public agencies in both countries? In other words, how does sovereignty operate in democratic states in times of emergency, how was the chosen course of action received by the population, and was there a popular consent to the restrictive measures taken by the state authorities? Second, what were the supportive measures behind the political decisions to temporarily limit citizens' freedoms and rights, and how did the mechanisms of governmentality adjust to sovereign decisions? Finally, to what extent did the COVID-19 crisis reveal the ongoing transformations within the liberal order and its principles?

The juxtaposition of Finland and Estonia in this research context is justified by a number of reasons. They are two neighbouring countries located at the EU's eastern border, relatively small in population and culturally, ethnically, and linguistically close to each other, belonging to what is known as the 'Finno-Ugrian world'. From a political perspective, both countries are parliamentary republics run by coalition governments, and they were among the first countries in Europe to reopen borders for travel in June 2020, after almost 3 months of lockdown. 
When it comes to the situation on the ground (see Table 1), by the end of the emergency, 86,659 Estonians had been tested negative and 1910 positive. 347 infected Estonians had been hospitalised and released, 19 remained in hospitals, and 69 patients had died. In Finland, the situation was rather stable before, during, and after the lockdown, with under 7000 tested positive mainly in the metropolitan area of Helsinki. As of 14 May 2020, the National Infectious Disease Register showed that the number of confirmed cases amounted to 6145 , with a total of 287 deaths, 5858 recovered, and 143 patients still remaining in hospital care. In addition, Finland and Estonia have the lowest curves of COVID-19 spread in relation to the population among the countries in the region (see Fig. 1 below).

Our data include official documents of the two countries and media analysis. In the case of Estonia, the researched time frame was identical to the period of emergency from 12 March to 17 May 2020. We collected information from the online resources of Estonian executive (Ministry of Social Affairs, Health Board, Office of the President, Ministry of Interior) and legislative (Riigikogu) institutions, financial organisations (Estonian Bank, Estonian Traders' Association), political parties and municipal authorities, the official website fully devoted to the COVID-19 crisis, as well as from two media sources - the ERR TV channel and Postimees newspaper, which both have Estonian, English, and Russian versions. In the case of Finland, the analysis comprises the pre-emergency stage in late February, the introduction of the restrictive measures, and their cancellation on 14 May 2020. The official documentation was sourced from the websites of the Finnish Government, think tanks, research institutions, and third-sector organisations dealing with pandemic management and giving expert advice on issues related to it; for example, the Finnish Institute for Health and Welfare (THL), Business Finland, and the Social Insurance Institutions Kela and Mela. Data on parliamentary and public debates were obtained from the Finnish public service broadcasting company Yle and several national newspapers, such as Helsingin Sanomat and Helsinki Times.

Structurally, the article is divided into four parts. We begin with a theoretical outline of the concepts used in our analysis. We then present the cases of Estonia and Finland in two separate sections. After that, we do comparative analysis by juxtaposing the two countries and looking at their anti-pandemic policies from the theoretical perspective of sovereignty, governmentality, and post-liberalism.

\section{COVID-19: A Valediction for Schmitt and a Test for Agamben}

Arguably, the COVID-19 crisis has strongly contributed to global transformations away from the doctrine of liberal values towards biopolitical instruments of protection and care-taking. This shift is key for the concept of post-liberalism, which makes the distinctions between democracies and non-democracies more complex and less binary (Shlomo 2020) largely due to the transformative dynamics within Western liberalism itself (Guo and $\mathrm{Hu} 2019$ ). The post-liberal momentum implies a reconsideration of the liberal 'faith in science and its capacity to correctly identify, fully grasp, effectively manage, and successfully ameliorate social, economic, and political dynamics' (Mavelli 2019, 227). One may say that 'liberalism abandons 
its universalistic aspirations' (Joseph 2016, 378) 'along with any natural claims to promote all life as a self-endowed subject with inalienable rights' (Evans and Reid 2013, 91). Correspondingly, post-liberalism shifts political agendas 'from the search for objective and universal laws to examining the practical consequences of acts' (Juncos 2017, 5) in specific policy domains. The 'therapeutic domination' characteristic of post-liberalism 'entails the expert application of an instrumentally rational technical procedure, typically a treatment protocol, to a subordinated individual or population in a situation of emergency, crisis, or disease, always to the supposed benefit of the treated' (McFalls and Pandolfi 2014). In this vein, 'liberal views emphasise the capacity to withstand and "bounce back", founded upon the classical liberal subject's capacity for rational behaviour. By contrast, the... post-liberal subject is relational rather than autonomous, meaning that it is embedded within a much more complex social environment' (Humbert and Joseph 2019, 216). Yet, these changes mark 'a shift rather than a full reversal' (Joseph 2013, 45) of the normative foundation of liberalism, and we assume that the COVID-19 pandemic contributes to this transformation-not towards a reversal of the liberal order (Dag 2020), but towards its adjustment and fine-tuning to new biopolitical circumstances.

Within the biopolitical realm, the growing feeling of existential anxiety has reinforced the concept of bare life, which was coined by the Italian political philosopher Giorgio Agamben and replicated by his multiple followers. In the biopolitical context, the idea of bareness connotes a sense of unprotected life beyond legal and institutional arrangements, a physical existence always endangered by forces beyond our control. Another of Agamben's favourite concepts is homo sacer, a metaphorical figure of a defenceless outcast whose life does not count much and whose potential death is not regarded as something exceptional or unusual. Finally, this biopolitical chain is complemented by the metaphor of the camp as an exemplification of a selfreproducing state of exception.

With the outbreak of the pandemic, Agamben claimed that the emergency was 'entirely unfounded', and the media was spreading 'a state of panic, thus provoking an authentic state of exception' disproportional to the situation (Agamben 2020b). He lambasted European societies for 'believing in anything but naked life'; the greatest danger today, he argued, is not the virus itself, but the fact that politicians are exploiting this situation to introduce heightened security measures and deploy a range of exceptional technologies of power (Agamben 2020c). He found in the coronavirus pandemic yet another vindication of his prediction of a 'global civil war' (Agamben 2020a), which resembles 'the Hobbesian model of the state of nature, and... the war of all against all' (Michelbach and Poe 2016, 250).

Apparently, Agamben's arguments implicitly resonated with a Schmittian understanding of politics. The German political philosopher Carl Schmitt described a situation of the 'suspension of the political law which introduces a state of higher emergency where normal rules of behaviour no longer apply... since the decision to suspend the norm cannot be deduced from the norm itself, it has to derive from the purely voluntaristic, extranormative dimension of the sovereign will... the norm loses its autonomy and becomes only a secondary result of the original decision, a mere "crust of the mechanism" behind which there lurks "the power of real life" (Bielik-Robson 2016, 297). The core of the Schmittian 
Table 1 Comparison of the two countries (The table was prepared by the authors, sourcing the data from: Terviseamet (2020) Koroonaviiruse andmestik. https://www.terviseamet.ee/et/koroonaviirus/koroo nakaart. Accessed 10 May 2020; and Finnish Institute for Health and Welfare (THL) (2020) Situation update on coronavirus. https://thl.fi/en/web/infectious-diseases/what-s-new/coronavirus-covid-19-lates t-updates/situation-update-on-coronavirus. Accessed 10 May 2020)

\begin{tabular}{lllcll}
\hline Country & Population & Reported cases & Deaths & Dates of the lockdown & $\begin{array}{l}\text { End of the } \\
\text { state of emer- } \\
\text { gency }\end{array}$ \\
\hline Estonia & $1,329,000$ & 1910 & 69 & 12 Mar-17 May 2020 & 17 June 2020 \\
Finland & $5,543,233$ & 6145 & 287 & 16 Mar-14 May 2020 & 16 June 2020 \\
\hline
\end{tabular}

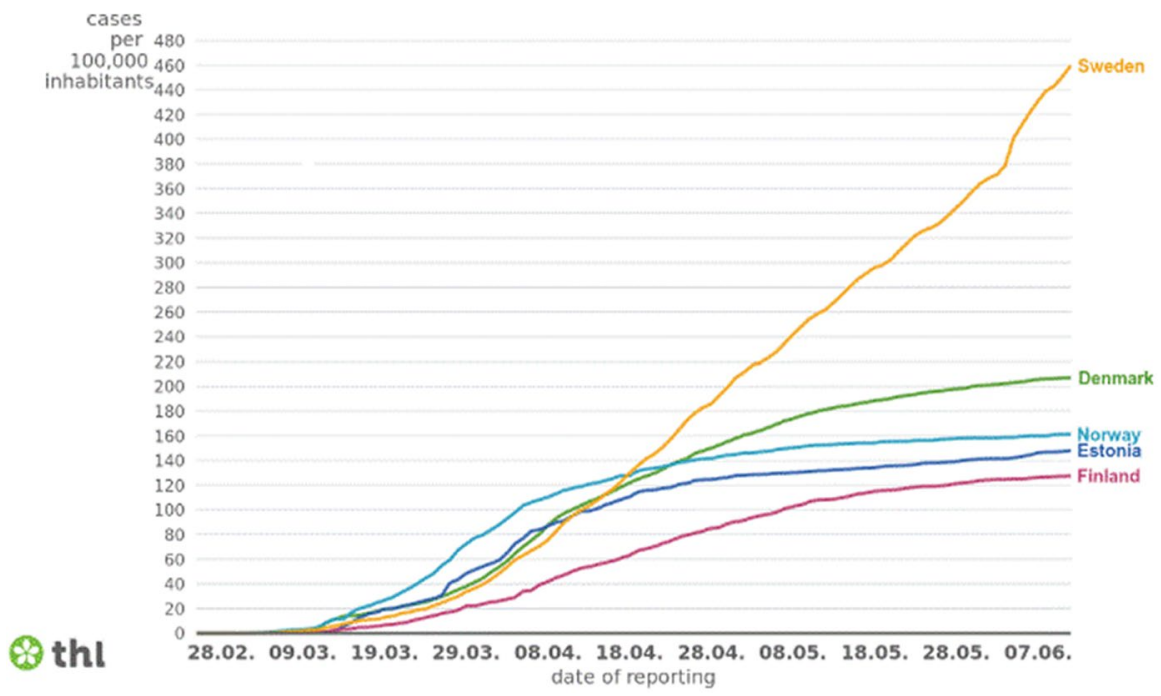

Fig. 1 The Finnish Institute for Health and Welfare's (THL) graph: confirmed COVID-19 cases in the Nordic countries and Estonia (excluding Iceland)

worldview is sovereign decisionism 'that seeks to counterbalance deliberative politics by correcting' (Hoelzl 2016, 236) its inability to make fast decisions. In a nutshell, 'right is made by the decision of a single person in a specific situation in which normal law is suspended. In the most dramatic moment of the state of emergency, the sovereign is making the decision and creates the right' (Hoelzl 2016, 237).

Apparently, 'Schmitt and Agamben belong to the same logic of sovereignty, occupying its opposite limit-cases' (Bielik-Robson 2016, 303): the former is focusing more on the decay of institutions under the state of exception and the advent of autocratic rule, while the latter is more interested in the biopolitical phenomenon of bare life, or a purely physical existence bereft of protection and sociality. Both are highly sceptical about liberal democracy and anticipate its failure, and build their philosophic narratives on the mythology of sovereignty 
(Michelbach and Poe 2016, 252). Both would agree that 'liberal governmentality, by governing less, seeks to govern more effectively, and, thus, ends up governing more' (Johnson 2014, 20).

Agamben's interpretation of the COVID-19 crisis was immediately rebuked by many public intellectuals. For example, Roberto Esposito was critical about comparing the quarantines to camps and prisons: 'to talk of risks to democracy in this case seems to me an exaggeration to say the least' (Coronavirus and... 2020). Agamben was criticised for his imbalanced emphasis on politically and ideologically biased declarations at the expense of empirical analysis (Berg 2020), and for the ungrounded conclusions that he infers (Christaens 2020) from the COVID-19 imbroglio. This polemic exchange of opinions created a fertile ground for further debate on the political dimensions of the global state of alert and brought to light new articulations of the demands for 'democratic biopolitics' (Schubert 2020). It became obvious that such over-generalisations as, for example, 'we are moving towards a global state of exception' need further specification: evidently, there are many varieties of exceptional steps and measures, which need to be empirically studied and compared with each other.

We contribute to this debate by positing that the COVID-19 crisis has exposed the inadequacy of the opposition between a state of exception - as an alleged prerogative of the sovereign power-and routine techniques of governance. A state of emergency, with multiple measures defined as exceptional, does not necessarily disavow the democratic procedures of governance. Very often, it is not the state that introduces the exceptional measures, but rather groups and organisations within society itself.

It is within this context that the title of this article has to be deciphered. The coronavirus crisis has dramatically undermined the whole logic of the Schmittian political philosophy of decisionist sovereignty due to two main reasons- the constitutive dependence of national governments on the techniques of governmentality and the irrelevance of the friend-foe distinction that Schmitt laid at the foundation of his vision of sovereign politics. In times of crisis management, it is biopower that 'orders the political rationalities and governmental technologies... [and] renders the friend/enemy distinction inoperable' (Dillon 2007, 24). In the meantime, the global state of alert became a test to Agamben's critique of the state of emergency. His usual over-generalisation and ontologisation of the concept of the camp appears vulnerable to criticism, yet, on the other hand, the coronavirus pandemic has drastically re-validated his other cherished concept, namely that of bare life. However, unlike Agamben, we see bare life not as a product of sovereign power, but as an existential condition of the fragility of human beings, which in times of crises grows exponentially into a security issue.

Against this backdrop, Foucault may be re-actualised as a philosopher who has shown 'that sovereign power is by no means sovereign, since its legitimacy and efficiency depend on a "microphysics of power" (Lemke 2011, 59). In David Chandler's words, from the viewpoint of post-liberal governmentality, 'sovereignty is no longer understood as something that inherits to state institutions per se, but rather as a variable quality or capacity for good governance' (Chandler 2010, 74). Foucauldian sovereignty is 'passive': his 'hollowing out of sovereign power [leads to] 
the revelation of a fundamental incapacity within sovereignty' (Dean 2010a, b). Foucault prioritised less politically pronounced 'technologies of the self' and 'rationalities of governing' based on 'knowledge/practices... that would enable individuals to refashion themselves' (Jose 2010, 690) on the basis of 'calculated tactics that guide everyday citizen-subjects to act in accordance with societal norms' (Ettlinger 2011, 538). The kernel of Foucauldian governmentality as a distinctive form of power is that 'although intertwined with the state, [it] cannot juridically be contained by the state. It cannot be appropriately restrained by its legal regulations and, as such, constitutes an excess vis-à-vis those regulations. This does not imply that "governmentality" is beyond all constraint; yet it does imply that mere legal regulations will not suffice... governmentality operates, so to speak, beyond the confines of the law... governmental techniques cannot, therefore, be appropriately blocked or contained by mere legal regulations' (Braeckman 2019, 2).

As Foucault $(2007,143)$ put it, '[i]n fact, we have a triangle: sovereignty, discipline, and governmental management, which has population as its main target and apparatuses of security as its essential mechanism'. Within this triad, governmentality has drastically changed the meaning of national sovereignty, transforming it from an analogue of divine power (Carl Schmitt) to biopolitical functions of care of human lives, along with the security of welfare institutions. The next passage exemplifies this phenomenon within today's context. On 1 April 2020, Prime Minister Sanna Marin began her address to the Finnish Parliament as follows: 'Mr. Speaker, the aim of the Government is to slow down and prevent the spread of the coronavirus in Finland, to safeguard the resource capacity and resilience of our healthcare system throughout the country, and to protect people, especially those at risk. ${ }^{1}$ Such a concern with the security of healthcare and education as part of the mechanisms of the welfare system illustrates what might be dubbed 'governmentalisation of government'. Developing the Foucauldian notion of governmentality that frames the population within apparatuses of security, Mitchell Dean has proposed a framework that focuses on the security of governmental mechanisms rather than the population and reveals a type of rationality where governmental technologies transform the mechanisms of governance to reduce costs and advance the efficiency of decisions. 'The question of security is central here. Social and liberal forms of government are correlates of a liberal problematic of security in which the welfare of each citizen and the population as a whole is dependent on the security of social and economic processes' (Dean 2010a, b, 223).

The post-liberal problematique of security shifts the emphasis from the tasks of regulating the population's health and ability to work for empowering individuals to exercise their autonomy and 'prudence' (O'Malley 1996a) to manage, minimise, or avoid possible risks. This transformation leaves much space for self-discipline, which is particularly important in times of security crises (Cameron 2007). In this regard, the 'state of exception' might be seen as one of the governmental strategies

\footnotetext{
1 Marin, Sanna (2020) Prime Minister Marin's speech at the referral debate in Parliament on 1 April 2020. Speech 207/2020. Prime Minister's Office. https://vnk.fi/en/article/-/asset_publisher/paaministerimarinin-puheenvuoro-eduskunnan-lahetekeskustelussa-1-4-2020. Accessed 10 May 2020.
} 
of security, a logic by which risk articulation and management transpire. It presupposes an imposition of sovereign restrictions within the national borders accompanied by the observance of the corresponding obligations by the population.

By the same token, the coronavirus pandemic revealed that governmental practices cannot fully rely on the power-knowledge nexus due to the very limited cognitive resources that decision-makers have at their disposal. Instead, the post-liberal administrative processes became dependent on the government's ability to redistribute sovereignty and responsibility across the agency of individuals and collectives. Furthermore, 'a democratic notion of accountability' (Peruzzotti 2019) appears to be crucial in the post-liberal mode of governance. Experts, healthcare workers, nurses, parents, teachers, and municipal authorities are those who each and all together perform the pre- and post-risk-related practices and techniques, and thus minimise the effects of the crisis on the state apparatuses. At the same time, they hold the state accountable by testing the value of political decisions through practice and precedents. Therefore, the sovereign-ridden and governmental policies are not mutually exclusive, and the feasibility of sovereign decisions is conditioned by individual 'practices of the self' (Foucault, 1988) and people's consent to sacrifice their usual lifestyles and personal liberties for the sake of collective interests.

\section{Sovereignty and Governmentality in Exceptional Times: The Case of Estonia}

The case of Estonia serves as a lucid illustration of the ambiguity and duplicity of sovereignty: on one hand, the bulk of practical mechanisms of governance was executed through responsibilisation and mobilisation of societal resources; yet, on the other hand, the government was heavily criticised for excessive interference in many sensitive spheres related to individual rights and freedoms.

\subsection{Responsibilisation: The Estonian Model}

With all the centrality of the Estonian government in the management of the crisis, in most realms, it relied on persuasion, rather than on direct enforcement. ${ }^{2}$ Since 'life always escapes governing' (Rose 2013, 209), there will always be 'places where the law cannot go' (Alves 2014, 324), which created a type of governmentality unfolding at the intersection of law and social norms. For example, as the government suggested, wearing medical masks in public was supposed to become a social norm, a recommendation, but not a legally enforced obligation. In the same vein,

\footnotetext{
2 The Prime Minister gave the Riigikogu an overview of the situation due to the spread of the coronavirus. Press release, 12 March 2020. https://m.riigikogu.ee/en/sitting-reviews/prime-minister-gave-riigi kogu-overview-situation-due-spread-coronavirus/. Accessed 23 June 2020.
} 
the Ministry of Education did not forbid final exams, but simply 'asked schools not to hold them'. ${ }^{3}$ As a warning signal, the state suggested that a complete lockdown could be introduced if citizens failed to obey the government's regulations.

A new realm of the state's interactions with private companies emerged, thus expanding the domain where sovereignty meets governmentality. The Estonian Foreign Ministry issued a public appeal to entrepreneurs, proposing that they should jointly identify goods and services to be internationally marketed with support from the state. ${ }^{4}$ A socially important initiative came from the Accelerate Estonia startup organisation, which sponsored the execution of the best ideas during the state of emergency with support from the Ministry for Information Technologies. ${ }^{5}$ The hackathon 'Hack the Crisis' in March 2020 involved more than 1300 people across 15 time zones and resulted in more than 30 ideas, of which eight have been developed further, including a coronavirus online testing system, a coronavirus tracker application, and an artificial intelligence-based device serving as a source of information and means communication in response to the pandemic. Along similar lines, the Estonian start-up community cooperated with Mistletoe Singapore and the European Commission to organise a 100-h free online accelerator for start-ups aimed at proposing practical solutions in the post-crisis world.

In many domains of crisis management, non-governmental actors took the lead in implementing important everyday measures. Volunteers were recruited through an online application, COVID-Help Zelos, ${ }^{6}$ and a psychological hotline ${ }^{7}$ was established. The Estonian Traders' Association called for protecting citizens in risk groups by abstaining from shopping during the morning hours, so that elderly people could visit stores without risking their health and engaged with the government to discuss measures to protect jobs and decrease economic losses. The Estonian Banking Union increased the sum of contactless payment to 50 euros. Another facet of responsibilisation concerned normalisation strategies: it was up to business operators themselves to decide when and how to resume their normal operations, and it was proposed that schools should decide themselves how to organise education after the end of the emergency period on 15 May $2020 .^{8}$

\footnotetext{
3 Minister Reps' address on the state examinations in Estonia in 2020. Ministry of Education and Research, 14 May 2020. https://www.hm.ee/en/news/minister-reps-address-state-examinations-eston ia-2020. Accessed 23 June 2020.

${ }^{4}$ Estonian Ministry of Foreign Affairs extends a helping hand to the Estonian entrepreneurs. 19 March 2020. https://vm.ee/en/news/estonian-ministry-foreign-affairs-extends-helping-hand-estonian-entreprene urs. Accessed 23 June 2020.

5 President of Estonia. Online hackathon Hack the Crisis.

15 March 2020. https://www.president.ee/en/official-duties/speeches/15882-online-hackaton-hack-thecrisis/index.html. Accessed 23 June 2020.

6 https://kogukondaitab.ee/en/i-want-to-help-others.

7 Republic of Estonia. 2020. Crisis hotline 1247 now offers psychological first aid. https://www.sotsi aalkindlustusamet.ee/en/news/crisis-hotline-1247-now-offers-psychological-first-aid?fbclid=IwAR1 0IayWtsJUO734761Z4sUPx6NeB5PX3XkgNYmr17sKbg0wKkMDmO1TESM. Accessed 27 March 2020.

${ }^{8}$ Education, Distant Learning and Exams. Official website of Estonian government. https://www.kriis .ee/en/education-and-distance-learning. Accessed 23 June 2020.
} 
As for strategic decisions, the government found itself between two 'governmental rationalities' (Villadsen and Wahlberg 2015) advocated by the securitisers and the normalisers. On one hand, the government itself was a key securitising actor, regularly reminding the public about possible gloomy scenarios and warning citizens about the entailing risks. ${ }^{9}$ In the meantime, demands for taking harsher measures against the virus, including a total ban on mobility within the country, came not from the government, but from hospital doctors and professional epidemiologists, as well as from civil activists who grouped on the 'Stop Corona' virtual platform. Such tropes as 'preparing for a battle' were articulated by medical doctors, paralleled by media reports about a 'military field hospital' being deployed on the island of Saaremaa with the highest numbers of infected across the country. The Rus.Postimees ${ }^{10}$ newspaper reported about its readers' multiple complaints about 'excessively liberal attitudes to violators of the self-isolation and social distancing rules'. The Mayor of Tallinn was also among those who pushed the central government to toughen the restrictive measures. ${ }^{11}$

On the other hand, on the opposite side of the debate were those who advocated the fastest lifting of the restrictions. The Bank of Estonia estimated that each week of lockdown would decrease the national economy by $0.5 \%$, which implied a loss of 140 billion euros per week. ${ }^{12}$ The 'normalisers' were reminding that the state forecasts of the number of seriously infected people overestimated the threat 20-fold. The head of an opposition party, ${ }^{13}$ demanding for a quick normalisation of everyday life, rhetorically asked: 'Why are museums gradually being opened, but not cinemas or cultural events? People read in the news that we have single-digit numbers of infected and do not understand why gyms are closed.' Other voices called for a broader public discussion on the validity of the restrictive measures and pushed the government to normalise the everyday rules on the presumption that, at certain point, people would cease to obey the emergency regulations. In the meantime, the former Finance Minister praised Sweden for refusing to introduce tough measures of emergency and 'keeping a positive spirit in society'.

Therefore, the Estonian situation was marked by an 'open-ended, reversible and multiplying set of governmental practices' (Villadsen and Wahlberg 2015), on one hand, and heated political debates with harsh criticism of the government, on the

\footnotetext{
9 The risk assessments of the Health Board under the conditions of reduced COVID-19 restrictions. Republic of Estonia, Health Board. https://www.terviseamet.ee/en/risk-assessments-health-board-under -conditions-reduced-covid-19-restrictions. Accessed 23 June 2020.

10 Postimees (2020) Граждане требуют суровых штрафов для нарушителей карантина и правила $2+2$ [Citizens require severe fines for violators of the quarantine and the two-plus-two rule]. https://rus. postimees.ee/6957648/grazhdane-trebuyut-surovyh-shtrafov-dlya-narushiteley-karantina-i-pravila-2-2. Accessed 24 April 2020.

11 Kõlvart: Further Developments Depend on Each of Us. Official website of Tallinn City Council. https ://www.tallinn.ee/rus/Uudis-Kylvart-razvitie-sobytij-zavisit-ot-kazhdogo-iz-nas. Accessed 23 June 2020.

12 A longer lasting crisis will inevitably lead to changes in the economy. Press release of the Estonian Bank. 14 April 2020. https://www.eestipank.ee/en/press/longer-lasting-crisis-will-inevitably-lead-chang es-economy-14042020. Accessed 23 June 2020.

13 https://eesti200.ee/.
} 
other. In the next section, we turn to the controversies of the government's modus operandi during the emergency.

\subsection{National Sovereignty and the State of Exception}

The strongest biopolitical contribution to the Estonian discourse on COVID-19 was made by the former President Toomas Hendrik Ilves, who assumed that the current pandemic crisis is a matter of survival of the Estonian nation, which apparently was supposed to underline the central role of the state in tackling the existential threat. The state indeed was in the limelight of the crisis management procedures, ranging from high politics (closure of borders, bans on public gatherings, police control over infected people's appearance in public spaces, and involvement of Kaitseliit, a voluntary defence league) to securing everyday routines (disinfection procedures in public places, control over the maximum capacity of customers in stores, limitations on purchase of paracetamol, etc.). Estonian officials notified the Council of Europe of the introduction of exceptional measures and submitted the government's derogations from the ECHR under Article $15 .^{14}$

Yet, these measures did not curtail democratic procedures of governance. For example, the order of the Health Department to temporarily discontinue dental treatment in private clinics was legally challenged by lawyers, the Ministry of Justice cancelled the decision of local authorities to close down certain public spaces from 'outsiders' as illegitimate, and a gymnasium's decision to cancel the spring vacation was overruled by the court upon the insistence of parents. The opposition overtly criticised the government for mishandling financial matters, and one of the government parties was specifically denounced for using the crisis for political self-advertising. Journalists were discussing how the crisis might affect freedom of information, and university professors and their research have never before been so valued.

However, many other governmental policies related to the state of exception were met with public discontent. The former head of the State Court was particularly critical of the discontinuation of regular treatment in hospitals and associated it and other questionable decisions with the sidelining of the parliament in the management of the crisis, which might eventually concentrate power excessively in the hands of the executive. Chancellor of Justice Ülle Madise ${ }^{15}$ admitted that a set of legal amendments passed during the state of emergency received criticism for handing too much potential power to state agencies (including the Health Board) and away from the parliament (Riigikogu) and even from the government itself. One indicator of the tensions between the governmental bodies was the resignation of

\footnotetext{
14 Estonian ambassador informed Council of Europe of emergency measures implemented in Estonia. Ministry of Foreign Affairs of Republic of Estonia, 28 March 2020. https://vm.ee/en/news/estonianambassador-informed-council-europe-emergency-measures-implemented-estonia. Accessed 18 August 2020 .

15 https://www.oiguskantsler.ee/en/protection-constitution.
} 
Merike Jürilo, director of the Health Board, due to her disagreements with the Ministry of Social Affairs on the anti-COVID-19 strategy. ${ }^{16}$

Estonian President Kersti Kaljulaid did not promulgate amendments to the Rescue Act and Weapons Act, citing inconsistencies with the Constitution. The amendments were intended to give the database used to process emergency calls in crisis situations access to health information system data concerning the provision and the time and place of provision of medical care or healthcare services to individuals. ${ }^{17}$ The head of the Estonian Bar Association, Jaanus Tehver, joined the critics by pointing to some legal deficiencies in Estonia's emergency legislation: 'If we compare laws passed in the Estonian and Finnish parliaments during the emergency situation, legal acts pertaining to solving the emergency situation in Finland explicitly have an expiration date. I cannot understand why this practice is not used here'. ${ }^{18}$

Kersti Kaljulaid was equally critical of the quality of the legislative process, arguing that the parliament "placed the government in the back seat in crisis management... it is certainly several large steps away from a state organisation in the way I want to see it in Estonia... Under the new law, the national government and even local governments will also be able to hide behind officials in emergencies, and will no longer have to make decisions that are often unpleasant for people. I trust Estonian officials and their professionalism, but the understandable role of elected politicians in making decisions in difficult times for the country is a value in itself for a democratic state. ${ }^{19}$

What had particular resonance were the government's restrictions in two spheres - the limitations imposed on foreign labour in general and Ukrainian seasonal workers in particular, as well as the uncertainty created for international students from non-EU countries. These policies have their roots in 2019 and were largely advocated by the right-wing Populist Party EKRE, whose members hold five of the 15 ministerial positions. The COVID-19 has additionally boosted EKRE's previous efforts to reduce the inflow of many categories of foreigners into Estonia. In particular, the Estonian Interior Ministry has lobbied a bill limiting the working hours of foreign students to $16 \mathrm{~h}$ per week and cancelling the grace period for foreign graduates of Estonian universities to stay in the country, as well as other similar

\footnotetext{
${ }^{16}$ Katri Raik: Aitäh, Merike Jürilo! [Thank You, Merike Jürilo!]. Social Democratic Party of Estonia, 16 June 2020. https://www.sotsid.ee/katri-raik-aitah-merike-jurilo/. Accessed 23 June 2020.

17 The Riigikogu decided to amend the Act on Amendments to the Rescue Act and the Weapons Act. Press release, 21 May 2020. https://m.riigikogu.ee/en/sitting-reviews/riigikogu-decided-amend-actamendments-rescue-act-weapons-act/. Accessed 23 June 2020.

18 Vahtla, Aili. 2020. Tehver: Support needed from state instead of total regulation in a crisis. ERR. https://news.err.ee/1093270/tehver-support-needed-from-state-instead-of-total-regulation-in-a-crisis. Accessed 22 May 2020.

19 Whyte, Andrew. 2020. President issues statement expressing controversial emergency law fears. ERR. https://news.err.ee/1090411/president-issues-statement-expressing-controversial-emergency-law-fears. Accessed 6 May 2020.
} 
measures. ${ }^{20}$ These policies, reinvigorated in times of the crisis, were rebuffed by the Estonian President.

This debate shows how the pandemic crisis can recontextualise the political distinctions between liberalism and democracy. The Estonian government acted within the framework of democratic procedures, yet due to its coalition nature, some of its policies - particularly those promoted by the nationalist/conservative party EKREwere ostensibly illiberal and provoked a public debate on whether Estonia was going to remain open to people's mobility as a key element of globalisation. ${ }^{21}$ These policies, in the meantime, were counterweighted by the Estonian President, whose liberal positions were an important element of the checks and balances in governance.

As the post-lockdown developments in Estonia demonstrated, the government was criticised more for a lack of leadership and adequate data in critically important spheres (such as information about countries visited by travellers entering Estonia or about citizens assigned to quarantine) than for usurpation of power. Many important resilience-enhancing initiatives came from Estonian civil society in general and its well-organized start-up community in particular, including its well-developed IT sector. Cases of voluntary self-restriction (such as the coordinated temporary closure of major night bars in the city of Tartu in August 2020) contributed to the prospects of responsibilisation when it comes to the implementation of new hygienic and behavioural standards. The government made clear that a conscious and wellthought out conduct of citizens was the key to success in the anti-COVID battle, which explains the gradual substitution of state-enforced prohibitive measures with framework recommendations addressed to specific municipalities, enterprises, and organisations.

\section{Smooth Governmentality of the Finnish Welfare State}

In April 2020, Prime Minister Sanna Marin, Minister of Education Li Andersson, and Minister of Science and Culture Hanna Kosonen reached Finnish children through a live video conference to answer their questions related to the coronavirus and address their concerns about the current situation. ${ }^{22}$ The ministers promised to return life to normal as soon as such a decision would be supported by health and education professionals. From our perspective, this event, considered by many to be a landmark in Finnish politics, can be regarded as a manifestation of bio-governmentality and showed the government's readiness to share its sovereignty in

\footnotetext{
${ }^{20}$ Restrictions concerning foreign workers to remain in force also after emergency situation ends. Republic of Estonia, Ministry of Interior. 20 May 2020. https://www.siseministeerium.ee/en/news/restr ictions-concerning-foreign-workers-remain-force-also-after-emergency-situation-ends. Accessed 23 June 2020.

21 Mathur, Abhishek. 2020. Are foreigners welcome in Estonia? Estonian World. https://estonianworld. com/opinion/abhishek-mathur-are-foreigners-welcome-in-estonia/. Accessed 10 May 2020.

22 Yle (2020) Finnish PM holds press conference for children. https://yle.fi/uutiset/osasto/news/finni sh_pm_holds_press_conference_for_children/11321623?fbclid=IwAR32LIIm7ZSubXgsK01bf6TvhkpK vgtGcl-8eyFGKYMFGwe_WlbzrVTEoGQ. Accessed 25 April 2020.
} 
decision-making with experts and activate the participation of healthcare workers, parents, teachers, local authorities, and, finally, children themselves.

\subsection{Political Agency and Technologies of Freedom and Autonomy}

Finland is a country whose values and cultural background, being firmly tied to human rights, are accompanied by a robust welfare model. As we can see, the direct interaction between the top officials and Finnish children characterises a regular channel of communication used by the Finnish government to approach targeted groups to boost a sense of solidarity and sustain resilience. Such a mobilisation of responsibility originated not only from the national and local authorities, but also from the public and private sectors, which in Finland possess a great deal of autonomy.

In late February 2020, the COVID-19 wave came to Finland with tourists returning from Italy, Spain, and Greece. At first, the control bodies did not take urgent measures apart from issuing general guidelines on post-travel self-quarantine and wearing protective equipment. Full awareness of the dangers arose with the outbreak of the virus in Italy and the WHO's declaration of the world pandemic. This recognition resulted in a range of coordinated actions from the business, education, and third sectors, which followed the recommendations of the Finnish Institute for Health and Welfare (THL) and the Foreign Ministry, but also had their own operational freedom. Thus, in early March, several Finnish universities and colleges closed their doors at their own discretion before the introduction of the emergency legislation.

Even though a majority of educational bodies reacted immediately to the governmental instructions given on 12 March 2020, the emergency policies were still of a recommendatory character with respect to employees, researchers, and managers, as in the Estonian case. Initially, the government's guidelines only concerned individuals travelling abroad and self-quarantined after return from business trips. Later on, remote work was 'highly recommended ${ }^{23}$ by most trade unions, professional associations, and funders. At this point, the national Social Insurance Institution Kela introduced several support schemes for self-quarantined individuals. All individuals (irrespective of household income) who had to stay at home, as well as families with small children, were entitled to a 'temporary epidemic support' of 723.50 euros per month. ${ }^{24}$ In this way, the responsibility for education and social well-being lay with families and individuals, while the economic risks were counterbalanced by the extended inclusiveness of the welfare system.

\footnotetext{
${ }^{23}$ The Association of Researchers and Teachers of Jyväskylä (Jytte). 2020. Membership letter 1/2020. The Finnish Union of University Researchers and Teachers. https://tieteentekijoiden-liitto.creamailer.fi/ email/5e60e6f52caf7. Accessed 13 March 2020.

24 Kela, the Social Insurance Institution of Finland. 2020. Kela has taken steps to prepare for a corona virus epidemic_-securing the processing and payment of benefits given priority. Press release. https:// www.kela.fi/web/en/-/kela-has-taken-steps-to-prepare-for-a-corona-virus-epidemic-securing-the-proce ssing-and-payment-of-benefits-given-priority. Accessed 13 March 2020.
} 


\subsection{State of Emergency and Robust Welfare Measures}

On 17 March 2020, Prime Minister Sanna Marin introduced to the Finnish Parliament the Emergency Powers Act 'to ensure that society as a whole-not only public authorities but also private individuals and businesses — can function under all circumstances'. The Act outlined a number of restrictions on the constitutional rights and everyday lives of individuals, which were eventually prolonged to a period of 2 months. They included closures of schools and public places, the self-isolation of elderly and other risk-group citizens, as well as restrictions on gatherings and travelling. However, contact teaching and pre-school care continued 'for the children of parents working in sectors critical to the functioning of society' and students with special needs, thus easing the burden on the societal operations via adaptive risk governance. Ten days later, these measures were followed by a lockdown of the Helsinki Metropolitan Area and the 'closure of restaurants, cafes and licensed premises for the purpose of preventing close contact of customers.' According to the government's assessment, these 'restrictions should improve the availability of intensive care and thus reduce the number of lives lost among those infected with COVID-19 and among others requiring intensive care. ${ }^{25}$

Such an amplification of the Emergency Powers Act was compensated by massive 'security packages' supporting various business sectors, education, arts and culture, entrepreneurs, freelancers, as well as private households. ${ }^{26}$ The related application procedures were simplified to a minimum; for example, time limitations were removed, entrepreneurs were entitled to apply for unemployment benefits even if their business still operated, ${ }^{27}$ and official bodies such as Kela accepted application attachments created by taking a picture of the required documents with a mobile phone. These financial provision mechanisms were implemented via professional associations (Business Finland), public organisations [Arts Promotion Centre Finland (Taike)], funds and endowments (Finnish Cultural Foundation, Jenny and Antti Wihuri Foundation), social insurance institutions (Kela, Mela), and banks (Finnvera). Guarantees and direct bailouts were offered to agencies that provided further redistribution of Grants and loans to the final recipients. For instance, individuals were entitled to receive the basic benefits from the unemployment fund and apply for a grant of 2000 euros to support their enterprise. In many respects, such a welfare approach ensured popular consent to the political leadership and justified national

\footnotetext{
25 Finnish Government. 2020. Prime Minister Marin's speech at the referral debate in Parliament concerning decrees on the use of specified powers under the Emergency Powers Act. https://valtioneuvosto. fi/en/article/-/asset_publisher/10616/paaministeri-marinin-puheenvuoro-eduskunnassa-valmiuslain-kaytt oonottoasetusten-lahetekeskustelussa-26-3-2020. Accessed 27 March 2020.

${ }^{26}$ Finnish Government. 2020. Government proposes extensive economic measures to minimise the impact of the coronavirus epidemic. https://valtioneuvosto.fi/en/article/-/asset_publisher/10616/hallitusesittaa-laajoja-taloustoimia-koronavirusepidemian-haittojen-minimoimiseksi. Accessed 20 March 2020.

27 Finnish Government (2020) Government submits supplementary budget proposal to Parliament due to the coronavirus. https://valtioneuvosto.fi/en/article/-/asset_publisher/10616/hallitus-antoi-eduskunnal le-lisatalousarvioesityksen-koronaviruksen-vuoksi. Accessed 20 March 2020.
} 
sovereignty over constitutional rights and freedoms. As many emphasised, ${ }^{28}$ strong leadership and a unified government coalition were the main factors of public support for the management of the crisis.

The introduction of a 15-billion-euro financial backing, which provided vital aid to the functioning of society, was the government's response to a joint plea from the trade union confederations SAK, Akava, and STTK and the employers' associations EK and KT. ${ }^{29}$ It was followed by multiple amendments to labour law, additional bailouts, and an easing of the regulation of seasonal work. At the request of the Ministry of Agriculture and Forestry and the MEAE Group ${ }^{30}$ the legislation was amended to let some 1500 foreign seasonal workers arrive in the country during the lockdown period and allow the employment of laid-off foreign residents in the agricultural sector, ${ }^{31}$ which substantially differed from the Estonian case.

\subsection{Avoiding Risks and Technologies of Self-help}

The Finnish way of governance entailed not only relations of authority and anticrisis policies, but also issues of self-care and identity. The extreme measures of the lockdown were accompanied by a range of technologies for citizens' empowerment and self-esteem as well as various modes of exercising freedom. Even before the closure of educational and public services, most Finns had already applied the rules of social distancing. Later, children were encouraged to go out and exercise alone by participating in the 'teddy bear hunt'. ${ }^{32}$ Originating from the US, the teddy bear challenge spread across Finnish neighbourhoods, making outdoor isolation activities more enjoyable. Meanwhile, volunteer activities such as home delivery of food largely maintained practices of avoiding potential danger among such high-risk groups as elderly people and people with chronic diseases.

The rules of social distancing were promoted online and offline. On Facebook, sharing (roskalava), second-hand (kirppis), and different community groups

\footnotetext{
${ }^{28}$ Kauhanen, Anna-Liina. 2020. Hallituspuolueet harppaavat poikkeusaikaan kannatuksen kasvaessa, perussuomalaiset yhä Suomen suurin puolue [Support for the government parties is on the rise during the exceptional situation, the Finns Party continues to be Finland's biggest party]. Helsingin Sanomat. https ://www.hs.fi/politiikka/art-2000006443015.html. Accessed 20 March 2020.

${ }^{29}$ Häggman, M (2020) Social partners' proposals to help businesses in the corona crisis. STTK. https:// www.sttk.fi/en/2020/03/20/25544/. Accessed 20 March 2020.

${ }^{30}$ Finnish Ministry of Economic Affairs and Employment 2020. 'The MEAE Group comprises of five government agencies, 15 Centres for Economic Development, Transport and the Environment, 15 Employment and Economic Development Offices, six companies plus three funds.' https://tem.fi/en/ government-agencies-and-companies-of-mee-group. Accessed 30 March 2020.

${ }^{31}$ Finnish Ministry of Economic Affairs and Employment. 2020. More than 30,000 potential employees available for seasonal work. https://tem.fi/en/article/-/asset_publisher/kausitoihin-tarjolla-tyontekijoitamyos-suomessa. Accessed 27 April 2020.

${ }^{32}$ Smith, Adam Oliver. Gallery: global 'Teddy Bear Challenge' arrives in Finland, keeps children active during shutdown. Helsinki Times. https://www.helsinkitimes.fi/finland/news-in-brief/17495-gallery-globa 1-teddy-bear-challenge-arrives-in-finland-keeps-children-active-during-shutdown.html. Accessed 31 March 2020.
} 
encouraged members to keep distance and halt second-hand habits for a while. ${ }^{33}$ Creative online solutions and inventive initiatives emerged and enabled novel ways of practising habitual activities and traditions remotely. For instance, the May Day ( уарри) celebrations of national solidarity, liberties, and labour rights were organized as a joint action of music groups, art projects, student unions, media providers, and local authorities, ${ }^{34}$ thus transforming high-risk spaces into an institutional landscape of active citizenship and participation. In the same manner, a number of for-profit educational and entertainment companies (e.g., Lukulumo-children's audiobooks) and projects (e.g., Espan lavan Virtual Open Stage 2020 35 -live music concerts) removed their paywalls for the lockdown period. These multiple efforts generated a virtual sense of community, made staying at home comfortable and enhanced trust between public authorities and individuals, which challenged Agamben's assertion that emergency inevitably leads to the demolition of liberal democracy.

Another effort to normalise anti-crisis practices can be seen in the forms of assistance, consultation, and psychological help offered by social insurance institutions, scholars, and experts. The Social Insurance Institution Mela organized a series of online workshops aimed to promote the well-being of Finnish and international researchers, placing an emphasis on psychological means of coping with stress and personal strategies of self-management. In the same vein, groups of experts from the Finnish Institute of Occupational Health, HiLIFE Helsinki Institute of Life Science, uMove Academic Sports of Jyväskylä, municipal care services and other companies provided guidelines for supporting the mental well-being, physical health, and remote working and studying abilities of various population groups.

This type of smooth welfare governance facilitates and encourages the targeted groups to exercise their freedom and become self-managing and prudent citizens. These practices of governmentality are 'reflexive', since they are concerned with 'indigenous' forms governance 'that arise in, and are endemic to, the everyday lives of subjects' (O'Malley 1996b, 313). It brings us to a conclusive observation in the Finnish case - the importance of risk calculation and production of knowledge in it. The Finnish 'reflexive' approach encompassed various forms of study including statistics and forecasting by public agencies and the Government COVID-19 Coordination Group ${ }^{36}$; sociological surveys carried out by industrial and public actors; academic research supported by the Academy of Finland and independent foundations;

\footnotetext{
33 One second-hand group included the following announcement: 'Now that we have an exceptional situation in Finland, please take it into account here when you sell and buy stuff. Agree with the buyer/seller in advance on how to hand over/pick up the products and avoid hand contact.' Jyväskylä Kirppis. https:// www.facebook.com/groups/738112292952744/announcements. Accessed 10 May 2020.

34 City of Helsinki. 2020. All times' Vappu at Home-virtual reality and live gigs offer programme for the whole family. https://www.hel.fi/uutiset/en/kaupunginkanslia/all-times-vappu-at-home. Accessed 28 April 2020.

35 Helsinki Channel. Current news about the coronavirus. https://www.helsinkikanava.fi. Accessed 30 April 2020.

${ }^{36}$ Finnish Government. 2020. Scientific support after the COVID-19 crisis: Government appoints COVID-19 scientific panel. https://valtioneuvosto.fi/en/article/-/asset_publisher/10616/tieteellista-tukea -koronakriisin-jalkihoitoon-covid19-tiedepaneeli-asetettu. Accessed 20 March 2020.
} 
and finally, efforts in risk screening and crisis prevention. ${ }^{37}$ All of these informed the official decisions and, to a certain extent, made it possible to deploy accurate strategic solutions through governmental programmes and welfare instruments.

The coronavirus situation exposed an aspect of the Finnish national tradition of rule that relies upon the political agency of the governed and their capacity for active engagement with local authorities, experts, and high-risk groups to seek and provide help. Crisis-ridden governance tends not only to produce-and function throughdifferent forms of freedom and responsibility, but also to enhance indirect means for the administration of people's agency. Therefore, to a certain degree, the advanced culture of responsibilisation and inclusive democratic institutions allowed Finns to successfully tackle the spread of COVID-19 and its socio-economic implications.

\section{Discussion: Comparing the Two Cases}

The distinction between liberal (values-based) and post-liberal (grounded in techniques of governance) orders appears to be an important frame for analysing the multiple transformations caused by the COVID-19 pandemic. The crisis has shown that for many governments, some liberal values are dispensable and can be temporarily discontinued for the sake of physical survival. Of course, there is nothing illiberal in the human life-centric mindset and the ensuing policies, yet in times of emergency, life-saving appeals might not necessarily correlate with a liberal understanding of democracy. In other words, the life-saving biopolitics comes at a certain price and implies changes within the doctrine of liberalism-its transformation towards efficient management of human bodies. Post-liberalism does not repudiate the basic principles of liberalism, but adjusts them to the imperatives of resilience and security; it is meant to reconcile the ideology of human rights and civil liberties with the practical necessity to secure human lives in a society of risk.

The crisis demonstrated that Agamben tends to go too far with his gloomy predictions, claiming, for example, that we are all homines sacri, or really or potentially 'killable' human beings whose physical existence cannot be guaranteed by any laws, norms, or institutions. On one hand, the coronavirus panic and its stillunknown, long-term repercussions moved the concepts of bare life and the camp away from the realm of purely academic debate to the real life of millions of people. Indeed, over the spring of 2020, we clearly saw how easily our normal lives, with their routine habits, pleasures, rules, and rights, were transformed into a constant concern about the very physicality of bare life with its focus on medicine. On the other hand, the lucidly exposed precariousness of bare lives is paralleled by the symmetrical vulnerability, if not evanescence, of sovereign power, and this is what is missing in Agamben's theorising. In times of crises, as we have seen, the state shares power with such practitioners on the ground as medical doctors, health workers, epidemiologists, virus experts, volunteers, producers of medical

\footnotetext{
37 Business Finland. 2020. Customer survey. https://www.businessfinland.fi/495b89/globalassets/finnishcustomers/news/news/2020/business_finland_survey_march_2020.pdf. Accessed 10 May 2020.
} 
equipment, etc. It became more apparent that the sovereign power is subordinated to the dictates of political economy (Clover 2020) and societal pressures. The decisions on multiple exceptions were therefore 'hardly a product of authoritarian desire on behalf of governments, which have, in general, been unprepared and slow to react, often responding to media pressure for further restrictions rather than leading and initiating. It is a peculiar state of emergency that leaves government leaders accused of "nonchalance" and "complacency" (Chandler 2020).

As for Foucault, the crisis has confirmed many of his theoretical premises and, first of all, the ideas of responsibilisation and governmentality. Crisis-ridden governmentality indeed ought to be approached as sets of practices "productive of specific subjects: the autonomous, organized, emergency-managing subject who... seeks to (re-)establish security' (Cavelty et al. 2015, 10). This resilient 'self-securing subject [accepts] the necessity of injunction to change itself' (Reid $2012,69)$, as opposed to the liberal paradigm of changing the world.

In the meantime, unlike in Foucauldian theorising, these concepts reach far beyond broadly understood liberalism and might be effectively applicable to the post-liberal Western world. Evidently, policy practices differ from country to country. What we have found peculiar in the case of Estonia is a clear call from the bottom for the government's sovereign decisions, which differs from the Finnish style of cooperation with expert agencies and governmental bodies. At the same time, Estonians quite often expressed reservations about the centralisation of authority and state intervention in the private lives of individuals, which was less an issue in Finland. For one thing, it might be explained by the post-Soviet experience that Estonians have and Finns do not. Besides, such a concern exposes both a problem in trusting the state apparatus and public demands for ready-made decisions and rules, while, in Finland, we observed closer relations between experts, political representatives, opinion leaders, and civil society.

Coming back to our analytical triangle of sovereignty, governmentality, and post-liberalism, we find that each of the three goes through intrinsic transformations. The concept of sovereignty increasingly moves away from its binary Schmittian reading ('us against them') towards a more inclusive and performative, relational and socially constructed understanding of power and politics. Governmentality gradually shifts from the welfare state's obligations towards its citizens to Foucault's responsibilisation, or individual or group-based forms of self-protection and self-conduct as key components of social resilience. Postliberalism, in its turn, implies a transition from projecting values to developing managerial and administrative capacities for inciting good governance.

In the meantime, the three concepts are deeply interconnected. In the context of the COVID-19 pandemic, sovereign power became even more dependent on the mechanisms and practitioners of governmentality as an anti-crisis set of policy measures and instruments. The post-liberal dynamics have even strengthened what is known as algorithmic and statistical governance in the practices of sovereign power. In addition, the post-liberal momentum has boosted the instrumentality of governance, which is at the core of the two crisis management strategies we have studied. 


\section{Conclusions and Implications for the EU}

In this article, we have addressed the nexus of sovereignty and governmentality during the state of exception of the COVID-19 emergency. Comparing Estonia and Finland, we have demonstrated that in neither Baltic Sea countries, the temporary concentration of power grew into authoritarian attempts of breaching the limits of political authority. On the contrary, the sovereign decisions of the governments were compensated through parallel financing and cost-sharing, which mitigated the crisis spots. In many respects, the success of COVID-19 management was conditioned by the adjustment of the mechanisms of governmentality and technologies of responsibility to new conditions of life, work, and leisure as core elements of the post-liberal order.

As we can infer from our analysis, the two countries had some differences and disagreements in their anti-epidemic policies. For example, Kristi Raik, director of the Estonian Foreign Policy Institute, assumed that the COVID-19 crisis dispelled Estonian hopes for 'special' (due to geographic and cultural proximity) relations with Finland, which closed its borders to most Estonians but left them open to Sweden, where the epidemiological situation was much worse. ${ }^{38}$ Another difference concerned policies towards seasonal workers from Ukraine: while Estonia has reduced their number to a minimum, Finland left the door open to them. Apart from that, in August 2020, Finland began to let in Russian citizens whose partners (not necessarily official spouses) reside on the Finnish side of the border, while Estonia kept its borders closed to all Russian citizens.

Despite the distinctions in their practices of tackling the pandemic, the two countries have shown a fair degree of interactive coordination of their policies when it comes to the closure and gradual opening of their borders-initially to Estonians having jobs in Finland, then to those travelling for urgent family reasons, and finally to all travellers. This combination of policy coordination and distinctions seems typical for the situation within the EU as a whole during and after the pandemic. The sense of official Brussels' inaction at the beginning of the crisis has pushed neighbouring countries to look for bilateral solutions in border management and information sharing to prevent the virus from spreading. Yet, at the same time, a lack of due coordination of the member states' domestic and foreign policies, including those related to the functioning of the Schengen Zone, has contributed to a broad diversification of these policies. Under these conditions, policy coordination became feasible either on a country-to-country basis, with some degree of reciprocity, or within a small group of countries (for example, between Estonia, Latvia, and Lithuania, which have a long record of developing joint policies in many areas). Arguably, regionalism - as exemplified, for instance, by the Council of Baltic Sea Statesfell victim to COVID-19, since, from a practical viewpoint, regional organisations did very little to fight the virus. Evidently, to boost intra-European solidarity, the

\footnotetext{
${ }^{38}$ Kristi Raik. COVID-19 crisis brought new realism to Estonian-Finnish relations. ERR, 26 June 2020. https://news.err.ee/1106419/opinion-covid-19-crisis-brought-new-realism-to-estonian-finnish-relations. Accessed 20 August 2020.
} 
EU will heavily invest in assistance packages to the most affected countries, in the meantime taking for granted the operational freedom of its member states to implement national policies in the management and administration of pandemic-preventing policies.

Acknowledgements Tatiana Romashko's contribution to this article was supported by the Kone Foundation (Koneen Säätiö).

\section{Compliance with ethical standards}

Conflict of interest On behalf of all authors, the corresponding author states that there is no conflict of interest.

\section{References}

Agamben, Giorgio. 2020a. Reflections on the plague. European Journal of Psychoanalysis. Translated from the Italian by Gianmaria Senia. www.journal-psychoanalysis.eu/reflections-on-the-plague/. Accessed 10 May 2020.

Agamben, Giorgio. 2020b. Lo stato d'eccezione provocato da un'emergenza immotivata [The state of exception provoked by an unmotivated emergency]. Il Manifesto, 25 February 2020. https:// ilmanifesto.it/lo-stato-deccezione-provocato-da-unemergenza-immotivata/. Accessed 19 June 2020.

Agamben, Giorgio. 2020c. L'épidémie montre clairement que l'état d'exception est devenu la condition normale [The epidemic clearly demonstrates that the state of exception has become a normal condition]. Le Monde, 24 March 2020. https://www.lemonde.fr/idees/article/2020/03/24/giorgioagamben-1-epidemie-montre-clairement-que-l-etat-d-exception-est-devenu-la-condition-norma le_6034245_3232.html. Accessed 19 June 2020.

Alves, Jaime Amparo. 2014. From Necropolis to Blackpolis: Necropolitical Governance and Black Spatial Praxis in São Paulo Brazil. Antipode 46 (2): 323-339.

Berg, Anastasia. 2020. Giorgio Agamben's Coronavirus Cluelessness. The Chronicle of Higher Education. https://www.chronicle.com/article/Giorgio-Agamben-s/248306?key=z5yodZPXH1 -Hi8hgwdp9akWH-jXrno6FVQZE24qkIFpuxgIOSVaMjuRtSAg7_1BhSjNkRkZwNTBOR1RVb U1DYWFwc0VzOU93TXZka2U1QVJRUkFwZGJhdE1Sbw\&cid=wsinglestory_41_1\&fbcli d=IwAR2R-19-8Qcdp4dRjDuqNMU1VDgd2HB5qjjqGzl5qquwjgxsVIMoF3-YAu4. Accessed 10 May 2020.

Bielik-Robson, Agata. 2016. Beyond sovereignty: Overcoming modern nominalistic cryptotheology. Journal for Cultural Research 20 (3): 295-309.

Braeckman, Antoon. 2019. Beyond the confines of the law: Foucault's intimations of a genealogy of the modern state. Philosophy and Social Criticism 2: 1-25.

Cameron, Robin W. 2007. Self-discipline in a Time of Terror: U.S. Foreign Policy and the U.S Self. Theoria 114: 74-101.

Cavelty, Myriam Dunn, Mareile Kaufmann, and Kristian Søby Kristensen. 2015. Resilience and (in) security: practices, subjects, temporalities. Security Dialogue 46 (1): 3-14.

Chandler, David. 2010. The EU and Southeastern Europe: The rise of postliberal governance. Third World Quarterly 31 (1): 69-85.

Chandler, David. 2020. The Coronavirus: Biopolitics and the rise of 'Anthropocene Authoritarianism'. Russia in Global Affairs, 6 April 2020. https://eng.globalaffairs.ru/articles/coronaviru s-authoritarianism/. Accessed 10 April 2020.

Christaens, Tim. 2020. Must Society Be Defended from Agamben? Critical Legal Thinking. https:// criticallegalthinking.com/2020/03/26/must-society-be-defended-from-agamben/?fbclid=IwAR1 dG0RzDyydZ8s0J8ATJdbX0y566E-DxdZ-tcCHoGupvheu6GPG4jcRi9s. Accessed 10 May 2020 . 
Clover, Joshua. 2020. The rise and fall of biopolitics: a response to Bruno Latour. In the Mount. https ://critinq.wordpress.com/2020/03/29/the-rise-and-fall-of-biopolitics-a-response-to-bruno-latour/. Accessed 30 March 2020.

Collier, Stephen J. 2009. Topologies of Power: Foucault's Analysis of Political Government beyond 'Governmentality'. Theory, Culture \& Society 26 (6): 78-108.

Coronavirus and philosophers, 2020. European Journal of Psychoanalysis. https://www.journal-psych oanalysis.eu/coronavirus-and-philosophers/. Accessed 19 June 2020.

Dag, Rahman. 2020. Reversal of Liberal International Order. Political Reflection 6(2): 20-22. https:// politicalreflectionmagazine.com/wp-content/uploads/2020/04/PR_Issue23-A2.pdf. Accessed 10 March 2020.

Dean, Jodi. 2010a. Drive as the structure of biopolitics: economy, sovereignty, and capture. Krisis 2 (8): $2-15$.

Dean, M. 2010b. Governmentality: power and rule in modern society, 2nd ed. London: Sage.

Dillon, Michael. 2007. Governing terror: the state of emergency of biopolitical emergence. International Political Sociology 1: 7-28.

Ettlinger, Nancy. 2011. Governmentality as Epistemology. Annals of the Association of American Geographers 101 (3): 537-560.

Evans, Brad, and Julian Reid. 2013. Dangerously exposed: the life and death of the resilient subject. Resilience 1 (2): 83-98.

Foucault, Michel. 1988. The History of Sexuality, Vol. 3: The Care of the Self. London: Sage.

Foucault, Michel. 2007. Security, territory, population. London: Palgrave.

Guo, D., and S. Hu. 2019. Identity politics and democratic crisis in western Europe. Chinese Political Science Review 4: 255-275.

Hoelzl, Michael. 2016. Ethics of decisionism: Carl Schmitt's theological blind spot. Journal for Cultural Research 20 (3): 235-246.

Humbert, Clemence, and Jonathan Joseph. 2019. Introduction: the politics of resilience: problematising current approaches. Resilience 7 (3): 215-223.

Johnson, Andrew. 2014. Foucault: critical theory of the police in a neoliberal age. Theoria 141 (61): $5-29$.

Jose, Jim. 2010. A (con)fusion of discourses? Against the governancing of Foucault. Social Identities 16 (5): 689-703.

Joseph, Jonathan. 2013. Resilience as embedded neoliberalism: a governmentality approach. Resilience 1 (1): 38-52.

Joseph, Jonathan. 2016. Governing through Failure and Denial: the new resilience agenda. Millennium Journal of International Studies 44 (3): 370-390.

Juncos, Ana E. 2017. Resilience as the new EU foreign policy paradigm: a pragmatist turn? European Security 26 (1): 1-18. (5).

Lemke, Thomas. 2011. Biopolitics: an advanced introduction. New York: New York University Press.

Mavelli, Luca. 2019. Resilience beyond neoliberalism? Mystique of complexity, financial crises, and the reproduction of neoliberal life. Resilience 7 (3): 224-239.

McFalls, Laurence, and Mariella Pandolfi. 2014. Therapeusis and parrhesia. In Foucault now, ed. James Faubion, 168-187. Cambridge: Polity Press.

Michelbach, Philip A., and Andrew Poe. 2016. New authority: Hamlet's politics with (and against) Carl Schmitt. Journal for Cultural Research 20 (3): 247-265.

O’Malley, Pat. 1996a. Foucault, government and the enfolding of authority. In Foucault and political reason: liberalism, neoliberalism and rationalities of government, ed. Andrey Barry, Thomas Osborne, and Nicolas Rose, 209-230. London: University College London.

O’Malley, Pat. 1996b. Indigenous governance. Economy and Society 25: 310-326.

Peruzzotti, E. 2019. Post-liberal and post-populist democracy: rethinking democratic representation. Chinese Political Science Review 4: 221-237.

Reid, Julian. 2012. The Disastrous and Politically Debased Subject of Resilience. Development Dialogue 58: 61-99. Uppsala: The Dag Hammarskjöld Foundation.

Rose, Nicolas. 1996. Governing 'advanced' liberal democracies. In Foucault and political reason: liberalism, neoliberalism and rationalities of government, ed. Andrey Barry, Thomas Osborne, and Nicolas Rose, 37-64. London: University College London.

Rose, Mitch. 2013. Negative governance: vulnerability, biopolitics and the origins of government. Transactions of the Institute of British Geographers 39 (2): 209-223. 
Schubert, Karsten. 2020. Crying for repression: populist and democratic biopolitics in times of COVID-19. Critical Legal Thinking. https://criticallegalthinking.com/2020/04/01/crying-forrepression-populist-and-democratic-biopolitics-in-times-of-covid-19/?fbclid=IwAR3NLZX1 M4h9Li5b46LX47ECvpitrCc0LV7RsuijGIYEsigwER_WFZphhLg. Accessed 10 May 2020.

Shlomo, Ben-Ami. 2020. Why democracies are better at managing crises. The Strategist. https://www. aspistrategist.org.au/why-democracies-are-better-at-managing-crises/?fbclid=IwAR3W_qG3PG UnJR1fz6gzuLudnhWVQkKyQ4qoPNs_hrUGpq9Dyogz_re60xg. Accessed 10 March 2020.

Villadsen, Kaspar, and Ayo Wahlberg. 2015. The government of life: managing populations, health and scarcity. Economy and Society. https://doi.org/10.1080/03085147.2014.983831.

Andrey Makarychev is a Professor at the Johan Skytte Institute of Political Studies, University of Tartu. His fields of expertise include biopolitics and cultural interpretation of political concepts. His recent publications include co-authored (all with Alexandra Yatsyk) monographs 'Critical Biopolitics of the PostSoviet: from populations to Nations' (Lexington Books, 2020), 'Lotman's Cultural Semiotics and the Political' (Rowman and Littlefield, 2017) and 'Celebrating Borderlands in a Wider Europe: Nations and Identities in Ukraine, Georgia and Estonia' (Nomos, 2016).

Tatiana Romashko is a grant researcher and a $\mathrm{PhD}$ candidate at the University of Jyväskylä, Finland. Since 2010, she has been a senior lecturer at various universities of St. Petersburg, Russia. In 20172018, she was teaching in Master Program of Cultural policy at the University of Jyväskylä. Her research interests encompass Russian politics, cultural policy studies, cross-border cooperation between Finland and Russia, cultural governance and post-structural discourse theory. For the last five years, Tatiana Romashko was a grantee of the Herzen University Committee of High Education and Science in St. Petersburg in Russia and the Kone Foundation (Koneen Säätiö) in Finland. Her current research project is devoted to the development of state cultural policy in post-Soviet Russia. 